\title{
Loyalty and Agency Problems: Study Comparing France Tunisia
}

\author{
Dr. Ali Medabesh \\ Jazan University \\ E-mail: alim@jcba.edu.sa \\ Ati Abdessatar \\ Jazan University \\ E-mail: atiabdessatar@yahoo.fr \\ Dr. Theiri Saliha \\ Urmofib El Manar University \\ E-mail: saliha_theiri@yahoo.fr
}

Received: November 16, 2011 Accepted: November 29, 2011 doi:10.5296/ber.v1i1.1208

\begin{abstract}
Given the large effect of loyalty in the relationship managers and shareholders in resolving conflicts of interest, we will, in this work, present this link to the agency theory. Specifically, he is finding, from a reading grid of several previous studies on theories of agency, effective ways a manager can use to retain shareholders, and then we will test empirically through qualitative analysis.
\end{abstract}

Keywords: Retention strategy, Theory of agency, Loyalty

Classification JEL: G32 


\section{Introduction}

Following the strategies used by companies to manage the relationship with shareholders, such as loyalty, analysis on the subject of this strategy require governance capable of stemming the potential destruction of shareholder wealth and mitigate the problems presented in this relationship, as proposed by the agency theory.

In particular, the explanation of loyalty in terms of conflict in this relationship tends to win in a dominant approach. Indeed, much research shows that the role of loyalty is in a relatively narrow perspective in reducing conflicts of interest and value creation, as it is purely incentive in relation shareholders / directors (Monsen and Downs (1965); Desbrières (1988), Easterbrook (1984), Coffee (2005);-Gunesh Boolell, Broihanne and Merli (2008), etc.).. owever, as an emerging concept, often used in studies in marketing, loyalty pervades today the field of finance. Indeed, the proliferation of small shareholders in the capital of the company and the presence of a shareholder holding a significant share is an effective control of management. Significant control normally provides a high power to control persons and requires the leader to work fully in the public interest of investors. In addition, a shareholder may lose interest in a company in which the power of leaders is important. We can consider therefore that the pressure on the leaders is strong. Subsequently, conflicts of interest between shareholders and managers arise, influencing the decisions of investments. However, the presence of significant shareholders in the capital of the company is not a solution to these problems. The resolution of these issues led company officials to adopt strategies of shareholder loyalty.

The present work is therefore, from this perspective that seeks to develop a conceptual framework for understanding the intensity factors of retention in agency problems. In this context, we support the hypothesis that retention of such shareholders depends on the degree of distribution of dividends, a policy of transparent communication and detention of leaders of a share of the capital.

Specifically, this study aims to empirically verify this hypothesis in two different application fields and deepening the clarification of the role of loyalty in reducing agency problems.

\section{I: Theoretical development and hypotheses}

After returning to the objectives of managers and shareholders and a presentation of the costs of the relationship shareholders / managers, we propose a typology of the different incentives of both parties acting in this relationship and exposure assumptions that are subject to the empirical analysis.

\section{I-1: The relationship shareholder / manager}

To better understand our problem, we will identify the different objectives of each part of the relationship shareholder / manager.

\section{$\underline{\text { A/divergence of interests }}$}


i) The manager: According to the seminal work of Berle and Means (1932) which shows the ineffectiveness of American capitalism after the domination of corporate action by separating the functions of management and ownership, the concept of corporate governance was born with the emergence of these capital companies scattered here and the emergence of professional managers. Fama and Jensen (1993) refer to these executives in corporations as "Top Manager" and define their role in the management of the company. This function includes the proposal for the implementation of decisions regarding the structuring of contracts and allocation of corporate resources. It is reserved for the Chief Executive Officer in corporate America. Similarly, in French companies, the head is represented by the CEO.

The authors show that managerialist leaders receive some benefit related to their status in the company, they do not own. We cite, for example, the benefits of their remuneration and their personal prestige. Thus, in the absence of shareholder control, the leader embodies the company's resources to meet those goals. In particular, managers have privileged access to information from other business partners. They have the right to control information and, specifically, to delineate its availability to shareholders.

He manages the company in a way that does not comply with shareholder interests through three functions:

- The leader directs his attention to the maximization of income, status, power, prestige, and above all to preserve its security position.

- The manager seeks to maximize revenue and non-profit to ensure its place and make more power.

- The officer may make discretionary capital expenditures, as unprofitable projects (eg prestige operations).

ii) The shareholder: it owns shares of a company. However, an action does not mean a property of goods and services of the company, but simply a part of the net assets and profit distribution. However, ownership of the property is attached to the corporation that is "society". In case of failure, the shareholder does not support the losses in the amounts invested in shares held. It remains far from any duress or financial risk.

Therefore, an investor with a significant stake of the company is strongly encouraged to monitor the activities of managers. It has three functions depending on the study of Berle and Means (1932):

1 - Function of assumption of risk and uncertainty.

2 - Search function and coordination of inputs. She is described as the managerial function.

3 - Perceptual function related to the identification of profitable opportunities.

In the analysis of the property in Berle and Means, shareholders are supposed to be dispersed. They assume the only function assumption. For these authors, this passive function does not give the right to appropriate profit. It is attributed to shareholders exercising the two other functions that are described as active shareholders. 
In total, each part of the relationship shareholders / managers is seeking to maximize their personal interests. This research may lead the two parties not to meet its commitments because of their rationality. This is the agency problems.

\section{B- Agency problems}

Agency theory is an extension of the theory of property rights. It is based on the concept of agency relationship that helps to formalize the relationship between agents with different interests and determine the most appropriate incentives to different situations. The rise of agency theory is marked by an article published in 1976 in the Journal of Financial Economics, written by Jensen and Meckling (1979) on theories of the firm. According to these authors, there are in all corporations, a potential divergence of interest between the legal and financial authorities are bound by an agency relationship. In this theory, the company is described as a true knot of contracts in which a set of relations established between the different stakeholders.

Theorists call this agency relationship between managers and shareholders of contractual relationship can be defined as an agency relationship in which "one or more persons, (s) principal (to), commits (s) of another person (the agent) to act on his (their) name (s) a task involving a delegation of adjudicative "(Jensen and Meckling, 1976). By this definition, the contract between the manager and the shareholder has two essential characteristics:

1 - It means a representative function of the shareholder (the principal) by the leader (agent) in a given area.

2 - This is a contract with delegation of decision-making power to the leader of the shareholder.

The agency theory is based on two complementary assumptions: First, the objective of shareholders is profit maximization. On the other hand, the leader seeks to take advantage of the incompleteness of the contract (Charreaux, 1992). It is in this sense that the works on corporate governance have taken their starting point, and the arguments that favor the model "Shareholder" in which leaders must work in the interests of shareholders. There is therefore no reason to suppose that the manager and the shareholder have the same preferences. Indeed, the shareholder (principal) seeks to maximize its profit, while in some cases, the leader makes a decision for an investment project that will achieve a result opposite to the interests of shareholders without losing pay.

This divergence of interest gives rise to conflicts and agency costs, the nature and extent depend on several factors.

First, and consistent with the analysis of Jensen and Meckling (1976), there is a large gap between the objectives of maximizing the utility of managers and shareholder wealth. The leader tries to strengthen its position at the head of the company (Charreaux, 1997). He can spend the resources of the company in various fringe benefits. He prefers growth in turnover to that of profit. The goal is to serve the office of the company before meeting the interests of shareholders (profit distribution, upgrading of tracks, etc.).. This behavior reduces, accordingly, the value of the company and its future challenges. 
Then, the leaders refuse to invest in risky projects because the risks are similar. The officer may lose his job and especially its value in the labor market, while the shareholder loses only its inputs (Fama, 1980). In this context, Harris and Raviv (1990) add that, in the case of a company in difficulty, the leaders are encouraged to continue the implementation of current operations even if shareholders prefer liquidation of the company.

Finally, once the contract is signed and is guaranteed his position in the company, the leader behaves in an opportunistic manner because of information asymmetry in favor. It invests in specific projects and reduces effort. Many studies state that the management entrenchment is related to the behavior of non-maximization of shareholder wealth. Shleifer and Vishny (1989), Morck et al (1990) and Paquerot (1997) considered the root is the source of inefficiency in the work of the latter. They showed the negative effect of management entrenchment of shareholder wealth.

This behavior of management entrenchment and conflicts of interest occur agency costs. These are supported both by the shareholder and the manager: Minotoring costs, Bonding costs, Residual loss.

With this in mind the difference of interest is the question: What is the strategy and practices adopted to reduce agency problems? Subsequent developments have proposed governance arrangements as a solution to these problems. for illustrative purposes, debt, boards, incentive compensation, mechanisms for external controls. Shleifer and Vishny (1989), Jensen (1993) show that these mechanisms have limited effectiveness, hence the need to resort to other means, the focus will be on retention.

\section{I-2: The retention dilutes the problems of conflicting interests}

According to the pioneering studies of Jensen and Meckling in 1976, the agency theory looks specifically at issues of conflict of interests in joint stock companies, as appropriate, in addition, to mitigate them. In this case, an application of strategies to stabilize and shareholder loyalty is an alignment of interests. Such shareholder will be faithful and less incentive to monitor the activities of leaders and to make decisions detrimental to the interests of the company. Monsen and Downs (1965) show that large firms with a very diffuse shareholder seeking to reduce priority conflicts between various stakeholders and to maintain them in a stable relationship through:

\section{A- Stable dividend Policy}

The choice of a stable dividend policy and not fluctuating is treated as specific investment managers. Desbrières (1988) studied the choice and tests the appropriateness of adopting a dividend policy based on a survey with one hundred and thirteen small shareholders. It shows that the development of direct share ownership poses problems for companies privatized and more particularly to newly listed companies. He proposes as a solution to these problems, the loyalty of the population followed by a stable dividend policy. This author gives two conflicting objectives in dividend policy: if companies wish to attract and stabilize the small shareholders, they should follow a policy of distributing high. On the contrary, if they prefer to reduce the proportion of individual shareholders holding in the capital, it is sufficient to 
adopt a low rate of distribution. This proposal was resurrected by Calvi-Reveyron and Protin (2007) in an exploratory study on the problems of share repurchases in France. This study shows the positive impact of the strong presence of small shareholders on the dividend payment.

Contrary to the argument of neutrality of dividend policy demonstrated by Modigliani and Miller (1961), this policy is an effective tool for managing conflicts of interest problems. Indeed, a policy of stable distribution reduces the agency costs borne by the shareholders by encouraging managers to use more importantly direct funding and thus reduce the flow (Easterbrook, 1984).

Similarly, this hypothesis has been interpreted as a signal of profitability, attracting and motivating investors. In fact, the announcement of the dividend up or down indicate that leaders make public private information about the future of the company, thus reducing problems of asymmetric information. Calvi-Reveyron and Protin (2007) confirm empirically that the strong presence of problems of information asymmetry between managers and shareholders leads to a generous dividend policy. The payment of dividends solves, in a consistent manner, the problems of free cash flow related to the proposed investment. It has a supervisory role, monitoring, and incentives for executives to the shareholders.

Our first hypothesis is therefore:

H1: distribution dividend reduces problems of asymmetric information between managers and shareholders.

\section{B-Managers shareholders:}

The shareholder brings to the company equity. By cons, it expects a value corresponding to its investment risk. It is therefore essential to control the activity of managers to limit the actions adverse to his interest. But if the manager owns the business interests coincide and agency problems are reduced. Therefore, the shareholder manager encourages them to act in the interests of shareholders and meet their expectations.

This alignment of interests between the management authority and the providers of corporate funds emphasize the loyalty of shareholders and encourage them to retain their titles. Therefore, the manager devotes its efforts to maximize value.

These are the boards that choose the type of remuneration. They make more use of the stock option plans (POA). In this regard, there is abundant literature on the value of the formulas of the POA. The work of Jensen and Meckling (1976) are considered to be the first to show a positive relationship between the value of the business and all property rights owned by the leader. Confirming the results of the study of Leland and Pyle (1977), under which property managers indicates the quality of investment projects carried out by the company.

Haugen and Senbet (1981) proposed a policy for granting stock options in order to reduce non-cash benefits managers and contribute to an investment strategy that better meets the interests of shareholders. Similarly, Desbrières $(1991,1997)$ analyzes the role of POA in 
increasing the value of the company by reducing monitoring costs borne by shareholders but by encouraging leaders to retain only profitable projects and large sizes.

Despite the many advantages of the POA, they have limitations on improving the long-term performance of the company and the dilution of the wealth and power of shareholders.

The POA are formulas by which share the shareholders or other owners of the business leaders and give employees the opportunity to purchase shares of the company they manage. The purchase price or subscription is fixed at date of issue of options and remains fixed throughout the period of the offer.

These options are applied by listed and unlisted companies with limited liquidity and whose growth opportunities are very high. In Tunisia, the legal framework on the rules of stock options was established by Law No. 99-101 in December 1999. At first he limited the application of this scheme to some companies in the services sector, engineering, new technologies of communication. Then, this scheme has been generalized to include other sectors.

The POA has three general characteristics:

1 - The duration of exercise: this time is determined by the assembled shareholders and determines the deadline after which the option is exercised or waived.

2 - during the year: the purchase price of the underlying asset (as financial stocks or shares) that is set by the special meeting.

3 - The bonus: it concerns the price of a currency option buyer pays the seller of the option at the conclusion of the contract.

In sum, the POA can, firstly, to regulate conflicts of interest between managers and shareholders and to limit conflicts especially on the volume and the risk of investment projects (Desbrières, 1999). On the other hand, they contribute to the creation of shareholder value.

H2: There is a positive relationship between managers and shareholders, the shareholder loyalty.

H'2: The attention of shareholders is oriented managers the evolution of the share price, which implies a mitigation of conflicts of interest.

\section{C-Policy of regular communication to shareholders}

Some companies are limited to only publish the information and legal requirements, while others choose to voluntarily disclose the information. As part of the contractual theory of the firm, the choice of voluntary publication due to lower agency costs between shareholders and managers. Recall that agency costs are divided into cost control, cost of clearance and residual losses. Agency theory assumes that the costs of customs and monitoring increase with the fraction held by the public.

To reduce the problems of conflicting interests, the interests and good management have to choose a policy of transparent, efficient and permanent. In particular, the news program's aim 
is to meet legal and regulatory obligations to inform the shareholders on the company's situation and create a special relationship with the environment.

This communication policy has become the most effective tool for retention and uptake of shareholders. It aims to reduce the information gap between the power of management and financial power and limit potential opportunistic behavior of managers (Singh and Sirdeshmukh, 2000).

The large separation between shareholders and managers creates an important need for information. This need decreases with greater confidence of the shareholders to the strategies of leaders: the leader voluntarily disseminates relevant information to the public to show its good management, thereby reducing the costs of customs clearance. Similarly, monitoring costs borne by the shareholders are mitigated, if the shareholders would be encouraged by a policy of voluntary disclosure that meets their information needs. Subsequently, the agency costs decrease due to a relationship of trust of the shareholder who is better informed. The latter supports the development of the company by monitoring and evaluation of these projects and is possibly a support in case of difficulty.

The intrusion of a shareholder can significantly change the structure of capital ownership and upset, and the relationship between shareholders and managers, so managers are always encouraged to communicate well, and are also the reason explaining that the stability of the shareholders is the constant concern of those responsible for large corporate groups. Similarly, in cases of poor performance, another reason pushing managers to disclose private information to the public is related to the risk of change, thus maximizing the value of the company.

The major hypothesis of this section is that a policy of regular communication intended for small carriers satisfy their need for information and that this policy, in turn, reduces problems of asymmetric information.

The point raised by this part is the fact that retention reduces the problems of conflict of interest between managers and shareholders as it is treated as an incentive mechanism and discipline from both sides of the contractual relationship. The assumptions detailed above are combined in the model presented in Figure 1:

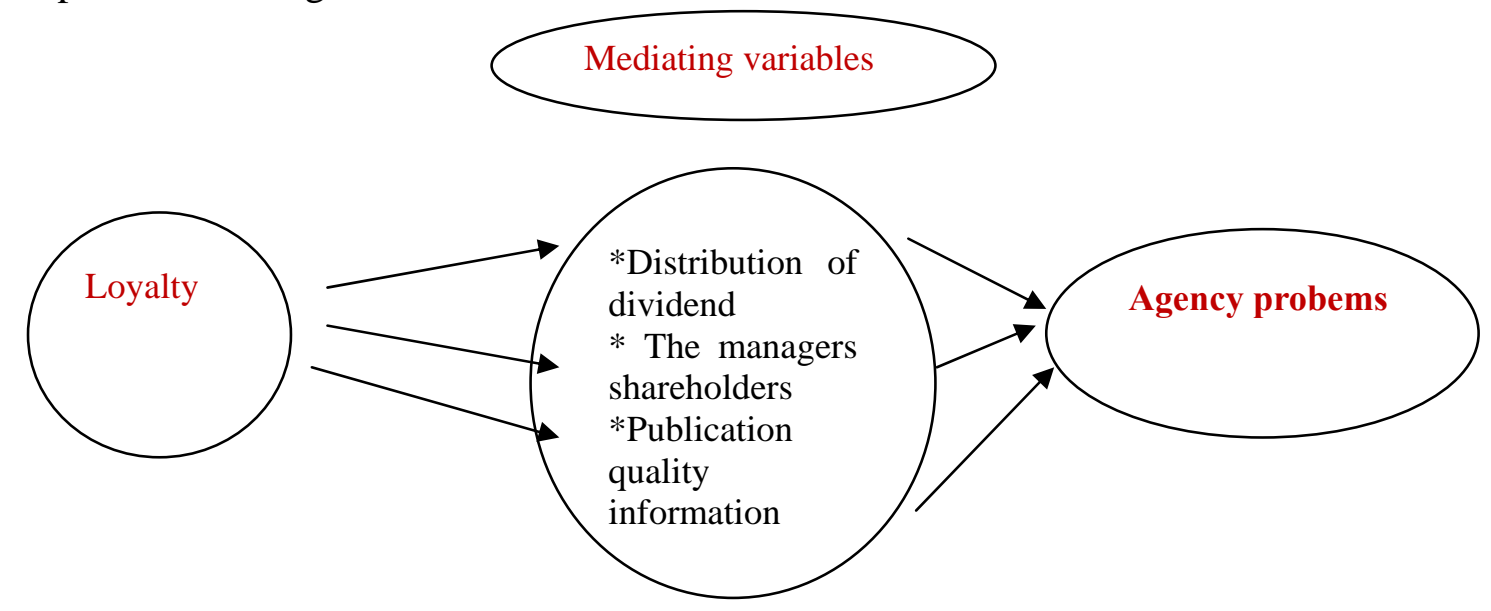

Figure 1. Loyalty- Agency problems 
Following this theoretical framework and the development of the game assumptions, we develop the empirical part of this research.

\section{II-Empirical Validation}

Two points will be discussed in turn: this is, first, to present the progress of the research methodology (method of data collection and measurement techniques selected) and then present the results of the study.

\section{II-1: The methodological path}

A- Data co llection: The method adopted for data collection to validate our assumptions outlined above is the questionnaire. In our case, this method is very relevant because it allows direct use of quality information and private decision-makers obtained themselves.

In addition, the use of quantitative methods can not verify some questions related to the perception of leaders, particularly in terms of divergence of interest and loyalty. Although relatively uncommon in finance, this methodology has been used to study the management practices related to the shareholder, such as studies Lemoine and Onne (2003), Labelle (2005), Bonnet (2005), Chakroun and Matoussi (2009), etc..

The questionnaire consists of questions designed to measure the determinants of loyalty in the relationship shareholders / directors. Some determinants are the subject of two or four questions in order to limit the risk of bais in the responses (Calvi-Reveyron and Protin, 2007). The questions are related to characteristics of the company's relationship management shareholders / directors. All these questions are measured on a Likert scale of 1 to 5 points. The questionnaire was sent, in 2009, the financial managers of nearly 80 French companies and 50 Tunisian companies listed. Despite several reminders, only 60 questionnaires were usable, $46 \%$ of the total sample. The questionnaire has been pre-tested with five fund managers.

We explain below the method of measurement of the variables used.

\section{B-The measure adopted}

The dependent variable: the agency problems

To know the objectives of the leaders, we used the variables used by the agency Ang et al (2002) which are respectively under-valuation, asymmetric information, the free cash flow and overinvestment. This determines whether the objectives of the leaders are the same as those of shareholders. This leads also to clarify how to use corporate resources to increase the activity and invest in profitable projects.

The explanatory variable: Loyalty

Loyalty is structured by four kinds of assumptions about the behavior expected of shareholders: trust, satisfaction, attracting new shareholders already close to the small shareholders and, increasing the holding period of shares. This variable was measured by a series of questions to approach these four dimensions derived from a previous investigation of the loyalty of the individual shareholder. 


\section{Mediating variables:}

- Managers shareholders, respondents indicate the part of managers' participation in the capital and specify if they are beneficiaries of the plan of share options or not.

- The dividend policy: this variable was measured by two dimensions on the adoption of a policy of non-fluctuating and stable distribution and its implications.

- Communications Policy: he was asked to indicate how the balanced relationship between shareholders and managers requires the publication of quality information and choice of communication tools well suited.

\section{II-2: Results of the study}

After providing a complete description of variables used, we will analyze the influence of the distribution of dividends, shareholders, managers and dissemination of relevant information on the behavior of shareholders.

\section{A- Descriptive Statistics}

Table 1 shows the means and standard deviations for each variable.

Table 1. Descriptive Statistics

\begin{tabular}{|c|c|c|}
\hline \multirow[b]{2}{*}{ Variables } & \multicolumn{2}{|l|}{ Mean $(\mathrm{Sd})$} \\
\hline & $\begin{array}{l}\text { French } \\
\text { companies } \\
(\mathrm{N}=40)\end{array}$ & $\begin{array}{l}\text { Tunisian } \\
\text { companies } \\
(\mathrm{N}=20) \\
\end{array}$ \\
\hline \multicolumn{3}{|l|}{ Loyalty } \\
\hline Increasing the length of detention of shareholders & $1,4(0,94)$ & $1,7(0,9)$ \\
\hline Satisfaction & $2(1,21)$ & $2,2(1,35)$ \\
\hline Confidence & $2,2(1,43)$ & $2,6(1,7)$ \\
\hline $\begin{array}{l}\text { The attraction of new shareholders already close to the small } \\
\text { shareholders }\end{array}$ & $2,8(1,28)$ & $1,9(0,84)$ \\
\hline \multicolumn{3}{|l|}{ Agency problems } \\
\hline The importance of publishing quality information to managers & $2,36(1,86)$ & $1,4(1,08)$ \\
\hline The informational advantage of shareholder directors & $1,3(0,47)$ & \\
\hline \multicolumn{3}{|l|}{ Stocks option } \\
\hline Share price & $1,9(1,41)$ & $2,4(1,22)$ \\
\hline Cash Investment Company & $1.9(0,95)$ & \\
\hline Investment projects selected & $4,1(1,33)$ & $3,4(1,37)$ \\
\hline \multicolumn{3}{|l|}{ Managers shareholders } \\
\hline The involvement of leaders in the capital of the company & $2,8(1,5)$ & $3,7(1,43)$ \\
\hline Stock option plan & $2,3(1,65)$ & $3,2(1,48)$ \\
\hline \multicolumn{3}{|l|}{ Communications Policy } \\
\hline The importance of adopting a communication policy & $1,6(0,94)$ & $1,4(0,67)$ \\
\hline Communication tools & $2,3(1,45)$ & $1,1(0,303)$ \\
\hline \multicolumn{3}{|l|}{ Dividends } \\
\hline Distribution of dividends & $1,6(0,68)$ & $1,2(0,4)$ \\
\hline Dividend Growth & $2,9(1,41)$ & $1,5(0,506)$ \\
\hline Degree from the importance of dividends & $2,4(1,39)$ & $3,5(1,5)$ \\
\hline Tax preference for dividends & $2,3(0,8)$ & $1,7(0,8)$ \\
\hline
\end{tabular}


The descriptive study of the various items used can get more interesting results. Indeed, from Table 1, it appears that:

* Retention is best explained by the confidence in French companies and the printing of former shareholders in the case of Tunisian companies.

* There is a very high level of information asymmetry in the sample Tunisia.

*In addition, shareholders leaders are better informed about the activities of the company as other shareholders, in the case of French firms (the average is 3.7).

*The problems of divergence of interest vary widely across the various indicators. There are problems related to the existence of free cash flow. The liquidity of the company are not placed in profitable projects and are used to increase the privileges of leadership. For businesses Tunisian leaders to invest in projects reported by the shareholders and generate a decline in equity values.

*Finally, the various mediating variables, we note that in the Tunisian companies, the participation of leaders in the capital is very large and they are the beneficiaries of stock option plans. A natural explanation of the high value of the mean would be that companies are mostly family.

On the other hand, we recall that French companies use a very transparent communication strategy in managing the relationship with individual shareholders. The proof is: most companies publish annual reports or on their web sites, a section on communications and relations with individual shareholders. This practice is almost non-existent in the Tunisian companies.

Recall that our research model is causal. The method of analysis of causality will be the method of structural equation that is used for large sample sizes (typically 200 to 300 observations). However, the small size of our sample does not use it. Therefore, we will have to use a correlation test Spearman rank which is specified as a non paramétrique8 test. This test allowed us to test the dependence of these variables.

The development below shows the correlation coefficients obtained and the comments of the results.

\section{B-Loyalty and agency problems}

The research hypotheses are made up of several variables. To verify, we chose to estimate, first, each variable by the method of principal component analysis for the correlation matrix. Then we crossed the two scores. The choice of this method is dictated by the applicability to the variables consist of several items (Evrard, Pras and Roux, 2000). The following tables present the final results of this correlation.

\section{H1: Dividend policy and asymmetric information}

To test this hypothesis we correlated the scores of the variables in pairs (the scores of the variable information asymmetries and distributions of profits). The results of this correlation are obtained in the following tables: 
i) The case of French companies correlations

\begin{tabular}{|l|l|l|l|}
\hline \multicolumn{2}{|c|}{ Sperman's rho } & Dividende Asymetrie & \\
\hline & $\begin{array}{l}\text { Dividende } \\
\text { Corrélation Coefficient }\end{array}$ & 1,000 & \\
\cline { 2 - 4 } & Sig. (2-tailed) &. & $-0.031^{* * *}$ \\
\cline { 2 - 4 } & $\mathrm{N}$ & 40 & 0.003 \\
\cline { 2 - 4 } & $\begin{array}{l}\text { Asymétrie } \\
\text { Corrélation Coefficient }\end{array}$ &,$- 031\left(^{* *}\right)$ & 40 \\
\hline & Sig. (2-tailed) & 0.003 & 1.000 \\
\hline & $\mathrm{N}$ & 40 & 404 \\
\hline
\end{tabular}

** Correlation is significant at the 0.01 level (2-tailed).

ii) The case of Tunisian companies correlations

\begin{tabular}{|c|c|c|c|c|}
\hline & & & Dividende & Asymétrie \\
\hline \multirow[t]{6}{*}{ Spearman's rho } & Dividende & Corrélation Coefficient & 1,000 &,- 431 \\
\hline & & Sig. (2-tailed) & . & 066 \\
\hline & & $\mathrm{N}$ & 20 & 19 \\
\hline & Asymétrie & Corrélation Coefficient &,- 431 & 1,000 \\
\hline & & Sig. (2-tailed) & ,066 & - \\
\hline & $\mathbf{N}$ & & 19 & 19 \\
\hline
\end{tabular}

** Correlation is significant at the 0.01 level (2-tailed).

The results of this test indicate that the dividend payout is negatively correlated with the presence of a sense of leadership information than the shareholders about the company's business, in French companies at the $1 \%$ and Tunisian companies at $10 \%$. According to hypothesis $\mathrm{H} 1$, the distribution of dividends encourages shareholders to retain a greater extent their shares, thereby reducing information asymmetries between owners inside and outside the company and allowing it to cut costs treatment related (Mott and Zarlowski, 2003).

H2: Managers shareholders and retention

To test this second hypothesis, we perform the same step that was used for the first hypothesis. We obtained results not significatifs10 for both companies.

We will try now, to apply the test by the correlation of each sub-sample for each variable:

\section{i) The case of French companies correlations}




\begin{tabular}{|c|c|c|c|c|}
\hline & & & $\begin{array}{l}\text { Managers } \\
\text { shareholders }\end{array}$ & retention \\
\hline \multirow[t]{6}{*}{ Spearman's rho } & $\begin{array}{l}\text { Managers } \\
\text { shareholders }\end{array}$ & Corrélation Coefficient & 1,000 & ,470(**) \\
\hline & & Sig. (2-tailed) & . & ,002 \\
\hline & & $\mathrm{N}$ & 40 & 40 \\
\hline & retention & Corrélation Coefficient &, $470(* *)$ & 1,000 \\
\hline & & Sig. (2-tailed) & 002 & . \\
\hline & $\mathbf{N}$ & & 40 & 40 \\
\hline
\end{tabular}

Correlation is significant at the 0.01 level (2-tailed).

In the case of the French sample, the only significant positive relationship at the $1 \%$ is variable between leaders beneficiaries of stock option plans and shareholder satisfaction. This means that, if the leader is the beneficiary of many actions, he is challenged to work in the interest of shareholders, thus increasing their confidence and increase the duration of ownership of shares, resulting in therefore, the satisfaction of the latter.

ii) The case of Tunisian companies correlations

\begin{tabular}{|c|c|c|c|c|}
\hline & & & $\begin{array}{l}\text { Managers } \\
\text { shareholders }\end{array}$ & retention \\
\hline \multirow[t]{6}{*}{ Spearman's rho } & $\begin{array}{l}\text { Managers } \\
\text { shareholders }\end{array}$ & $\begin{array}{l}\text { Corrélation } \\
\text { Coefficient }\end{array}$ & 1,000 &,$- 461(*)$ \\
\hline & & Sig. (2-tailed) & . & ,041 \\
\hline & & $\mathrm{N}$ & 40 & 40 \\
\hline & retention & $\begin{array}{l}\text { Corrélation } \\
\text { Coefficient }\end{array}$ &,$- 461(*)$ & 1,000 \\
\hline & & Sig. (2-tailed) & ,041 & . \\
\hline & $\mathbf{N}$ & & 40 & 40 \\
\hline
\end{tabular}

** Correlation is significant at the 0.01 level (2-tailed).

In the case of Tunisian companies, we linked all the variables that measure the shareholders and directors of the variable length of detention of shareholders. The test between these two variables is negatively significant at 5\%: in firms where managers are shareholders, the duration of the investment of investors is less than 1 year. Investors prefer an independent officer of the company's business.

\section{H2 ': Convergence of interests}

This hypothesis for the attention of managers shareholders, the stock price and conflicts of interest between shareholders directors and other shareholders. To test this relationship, we linked the variables that explain manager's shareholders, the stock price and the problems of conflicting interests. 
i) The case of French companies correlations

\begin{tabular}{|c|c|c|c|c|c|}
\hline & & & $\begin{array}{l}\text { Manager } \\
\text { shareholder }\end{array}$ & $\begin{array}{l}\text { Cours } \\
\text { boursier }\end{array}$ & Divergence \\
\hline \multirow[t]{9}{*}{ Spearman's rho } & $\begin{array}{l}\text { Dirigeant } \\
\text { actionnaire }\end{array}$ & $\begin{array}{l}\text { Corrélation } \\
\text { Coefficient }\end{array}$ & 1,000 &, $537(* *)$ &,$- 427(* *)$ \\
\hline & & Sig. (2-tailed) & . & .000 & ,006 \\
\hline & & $\mathrm{N}$ & 40 & 40 & 40 \\
\hline & $\begin{array}{l}\text { Cours } \\
\text { boursier }\end{array}$ & $\begin{array}{l}\text { Corrélation } \\
\text { Coefficient }\end{array}$ & ,537(**) & 1.000 &,$- 963(* *)$ \\
\hline & & Sig. (2-tailed) & 000 & ${ }^{\circ}$ & 000 \\
\hline & $\mathbf{N}$ & & 40 & 40 & 40 \\
\hline & Divergence & $\begin{array}{l}\text { Corrélation } \\
\text { Coefficient }\end{array}$ &,$- 427(* *)$ &,$- 963(* *)$ & 1.000 \\
\hline & & Sig. (2-tailed) & ,006 & ,000 & . \\
\hline & $\mathbf{N}$ & & 40 & 40 & 40 \\
\hline
\end{tabular}

** Correlation is significant at the 0.01 level (2-tailed).

ii) The case of Tunisian companies Correlations

\begin{tabular}{|c|c|c|c|c|c|}
\hline & & & $\begin{array}{l}\text { Manager } \\
\text { shareholder }\end{array}$ & $\begin{array}{l}\text { Cours } \\
\text { boursier }\end{array}$ & Divergence \\
\hline \multirow[t]{9}{*}{ Spearman's rho } & $\begin{array}{l}\text { Dirigeant } \\
\text { actionnaire }\end{array}$ & $\begin{array}{l}\text { Corrélation } \\
\text { Coefficient }\end{array}$ & 1,000 & ,392 & ,355 \\
\hline & & Sig. (2-tailed) & . & ,087 & 125 \\
\hline & & $\mathrm{N}$ & 20 & 20 & 20 \\
\hline & $\begin{array}{l}\text { Cours } \\
\text { boursier }\end{array}$ & $\begin{array}{l}\text { Corrélation } \\
\text { Coefficient }\end{array}$ & ,392 & 1.000 &,$- 963(* *)$ \\
\hline & & Sig. (2-tailed) & 087 & . & 012 \\
\hline & $\mathbf{N}$ & & 20 & 20 & 20 \\
\hline & Divergence & $\begin{array}{l}\text { Corrélation } \\
\text { Coefficient }\end{array}$ & ,355 &,$- 550(* *)$ & 1.000 \\
\hline & & Sig. (2-tailed) & ,125 & ,012 & . \\
\hline & $\mathbf{N}$ & & 20 & 20 & 20 \\
\hline
\end{tabular}

* Correlation is significant at the 0.05 level (2-tailed).

The results of the Spearman correlation test in the French sample shows a positive and significant at $1 \%$ between managers and shareholders the evolution of stock price and a negative correlation between shareholders and management problems of divergence of interests in accordance with the hypothesis $\mathrm{H} 2$ '. Note the possible existence of a reverse causal effect in this case. Indeed, the problems of conflict of interest will be mitigated by the fact that managers have a stake and that they fully work to increase shareholder wealth. This result is 
important because it confirms that if there is separation of ownership and decision-making, samples of managers will be more important (Demstez, 1983).

In contrast, in the Tunisian sample, we find that managers do not affect the shareholder conflict of interest problems. For cons, the stock price is influenced by the shareholders of managers (the correlation between shareholders and managers of stock price changes is significant at $10 \%)$. The share price declines following the emergence of agency problems within the company (there is a negative and significant at the $5 \%$ from agency problems and the stock price).

H3: Publication of information, satisfaction of shareholders and the problem of information asymmetry

To test our third hypothesis, we correlated the variables explaining the publication of information, satisfaction of shareholders and the problems of asymmetric information.

i) The case of French companies correlations

\begin{tabular}{|c|c|c|c|c|c|}
\hline & & & $\begin{array}{l}\text { Publication of } \\
\text { information }\end{array}$ & $\begin{array}{l}\text { satisfaction } \\
\text { of } \\
\text { shareholders }\end{array}$ & $\begin{array}{l}\text { problem of } \\
\text { information } \\
\text { asymmetry }\end{array}$ \\
\hline \multirow[t]{9}{*}{ Spearman's rho } & $\begin{array}{l}\text { Publication } \\
\text { of } \\
\text { information }\end{array}$ & $\begin{array}{l}\text { Corrélation } \\
\text { Coefficient }\end{array}$ & 1,000 & ,425(**) &,$- 568(* *)$ \\
\hline & & Sig. (2-tailed) & . & ,006 & 000 \\
\hline & & $\mathrm{N}$ & 40 & 40 & 40 \\
\hline & $\begin{array}{l}\text { satisfaction of } \\
\text { shareholders }\end{array}$ & $\begin{array}{l}\text { Corrélation } \\
\text { Coefficient }\end{array}$ & ,425(**) & 1.000 &,$- 496(* *)$ \\
\hline & & Sig. (2-tailed) & ,006 & & ,001 \\
\hline & $\mathbf{N}$ & & 40 & 40 & 40 \\
\hline & $\begin{array}{l}\text { problem of } \\
\text { information } \\
\text { asymmetry }\end{array}$ & $\begin{array}{l}\text { Corrélation } \\
\text { Coefficient }\end{array}$ &,$- 568(* *)$ &,$- 496(* *)$ & 1.000 \\
\hline & & Sig. (2-tailed) & .000 & ,001 & . \\
\hline & $\mathbf{N}$ & & 40 & 40 & 40 \\
\hline
\end{tabular}

* Correlation is significant at the 0.05 level (2-tailed).

In the French sample, the variable publication of information is positively correlated with the variable shareholder satisfaction and negatively to the problems of asymmetric information. According to our hypothesis, it encourages managers to voluntarily disclose information to achieve economic goals and the rules and social norms (and Matoussi Chakroun, 2009). This result joins the results found in the study and Matoussi Chakroun (2009) conducted on the Tunisian context. 
Here, a sense of reverse causality may also be considered. The fact that leaders produce good management with shareholders, reduces problems of asymmetric and probably reinforces the satisfaction and confidence that they give them, while improving their relationship with them.

ii) The case of Tunisian companies correlations

\begin{tabular}{|c|c|c|c|c|c|}
\hline & & & $\begin{array}{l}\text { Publication of } \\
\text { information }\end{array}$ & $\begin{array}{l}\text { satisfaction } \\
\text { of } \\
\text { shareholders }\end{array}$ & $\begin{array}{l}\text { problem of } \\
\text { information } \\
\text { asymmetry }\end{array}$ \\
\hline \multirow[t]{9}{*}{ Spearman's rho } & $\begin{array}{l}\text { Publication } \\
\text { of } \\
\text { information }\end{array}$ & $\begin{array}{l}\text { Corrélation } \\
\text { Coefficient }\end{array}$ & 1,000 & ,121 &,$- 476(*)$ \\
\hline & & Sig. (2-tailed) & . & ,612 & ,039 \\
\hline & & $\mathrm{N}$ & 20 & 20 & 20 \\
\hline & $\begin{array}{l}\text { satisfaction of } \\
\text { shareholders }\end{array}$ & $\begin{array}{l}\text { Corrélation } \\
\text { Coefficient }\end{array}$ & ,121 & 1.000 & ,047 \\
\hline & & Sig. (2-tailed) & ,612 & . & ,849 \\
\hline & $\mathbf{N}$ & & 20 & 20 & 19 \\
\hline & $\begin{array}{l}\text { problem of } \\
\text { information } \\
\text { asymmetry }\end{array}$ & $\begin{array}{l}\text { Corrélation } \\
\text { Coefficient }\end{array}$ &,$- 476(*)$ & ,047 & 1.000 \\
\hline & & Sig. (2-tailed) & ,039 & 849 & . \\
\hline & $\mathbf{N}$ & & 20 & 20 & 20 \\
\hline
\end{tabular}

* Correlation is significant at the 0.05 level (2-tailed).

There, in the sample Tunisia, one negative and significant correlation between the publication of information and asymmetric information. The relationship between shareholders and the satisfaction of the publication of information is not verified. This is explained by the opacity of publication policies and the lack of transparency. This result is expected in the sample since the Tunisian, the Tunisian financial market is characterized by uniformity, conservatism and discretion. In fact, the publication of information seems to favor the emergence of conflicts of interest between shareholders and managers because the information is handled by them. However, the satisfaction of shareholders is independent of the communication strategies adopted by companies. Shareholders prefer monetary benefits instead of informational advantages.

Overall, and based on empirical results generated from the last case, a policy of quality communication can mitigate both types of agency costs: So who wish to reduce the cost of clearing it supports, the manager has an interest to show good management policy for the voluntary disclosure of information. Of course for the shareholders who tend to encourage the adoption of a policy of voluntary publication to the extent that it would allow them to access information needed to evaluate policy manager, which limits the costs of monitoring incurred by the shareholders. 


\section{Conclusion}

The main interest of this work lies in its contribution to the analysis of the behavior of managers and shareholders by reducing agency costs in terms of strategies used in managing the relationship.

It turns out, according to results released, that loyalty tends to reduce agency problems. In light of the statistical tests, we have demonstrated that monitoring of a policy of distribution of dividend growth, holding by managers of a considerable part of the capital of the company and, finally, the adoption a policy for reliable and transparent communication promote the convergence of interests and highlight retention.

Thus, reducing the problems of divergent interests of different stakeholders increases the ability of the company to generate returns greater than costs. This excess cash flow is treated as an economic value of the company. This causal relationship is therefore the question about the role of loyalty in the creation of value.

\section{References}

Boolell-Gunesh S., Broihanne M. et Merli M. (2008). Are french individual investors reluctant to réalise their losses? Working Paper, Large ULP, no.12.

Calvi-Reveyron et Protin P. (2007). Les rachats d'actions en France : Résultats d'une étude exploratoire, Gestao \& Regionalidade, Vol 23, no. 68.

Charreaux G. (1992). Mode de contrôle des dirigeants et performance des firmes, Finance Contrôle Stratégie, Vol 1, no. 2, pp 88-128.

Coffee J C. (2005). A theory of corporate scandals: why the U. S and Europe differ, Colombia Law School, The center for law and Economic studies, no. 274.

Desbrières P. (1988). Sociétés privatisées: comment stabiliser l'actionnariat direct, Revue Française de Gestion, pp 37-42.

Desbrières P. (1999). Motifs et conséquences de l'adoption des stock-options, Banque et marché, no. 43, pp5-17.

Easterbrook F. (1984). Two agency-cost explanations of dividends, American Economic Review, 74, pp 650-659.

Evrard Y. Pras B. et Roux E. (2000). Market : études et recherches en marketing, Dunod, 3éme édition.

Girard C. (2001). Une typologie de l'activisme des actionnaires minoritaires en France, Finance Contrôle Stratégie, Vol 4, no. 3, pp123-146.

Girard C. (2002). Les actionnaires minoritaires, Revue Française De Gestion, 2002/5; no. 141, pp183-202. 
Jensen M. C. ET Meckling W. (1976). Theory of the firm: Managerial behaviour, agency costs, and ownership structure, Journal of Financial Economics, Vol 3, no. 4, pp 305-360.

Monsen R.J. et Downs A. (1965). The behavior of the large managerial firm, Journal of Political Economy, Vol.7, pp. 221-237.

Mottis N. et Zarlowski P. (2003). Relations investisseurs et contrôle des marchés financiers, Revue Française De Gestion, 2003/6, no. 147 pages 161 à 172.

Oyer P. et Schaefer S. (2006). Costs of broad- based stock option plans. Journal of Financial Intermediation, 15, pp511-534.

Paquerot M. et Mtanios R. (1999). Structure de propriété et sous performance des firmes: une étude empirique sur le marché au comptant, le règlement mensuel et le second marché, Finance Contrôle Stratégie, vol 2, no. 4 pp157-179.

Singh J. ET Sirdeshmukh D. (2000). Agency and trust mechanisms in consumer satisfaction and loyalty judgements. Journal of the Academy of Marketing Science, 28, 1, pp 150-167.18

\section{Copyright Disclaimer}

Copyright reserved by the author(s).

This article is an open-access article distributed under the terms and conditions of the Creative Commons Attribution license (http://creativecommons.org/licenses/by/3.0/). 